\title{
Bioaccumulation of Metals in Eels Taken From Lakes Köyceğiz (Turkey) and Võrtsjärv (Estonia) and Health Risk Assessments
}

\section{Ahmet Demirak ( $\sim$ ademirak@mu.edu.tr )}

Mugla Sitki Kocman Universitesi https://orcid.org/0000-0002-6815-8037

\section{Feyyaz Keskin}

Muğla Sıtkı Koçman Üniversitesi: Mugla Sitki Kocman Universitesi

\section{Maidu Silm}

Estonian Marine Institute: Eesti Mereinstituut

\section{Nedim Özdemir}

Muğla Sıtkı Koçman Üniversitesi: Mugla Sitki Kocman Universitesi

\section{Dilek Yıldız}

Muğla Sıtkı Koçman Üniversitesi: Mugla Sitki Kocman Universitesi

\section{Priit Bernotas}

Estonian Marine Institute: Eesti Mereinstituut

\section{Burak Öğlü}

Estonian Marine Institute: Eesti Mereinstituut

\section{Research Article}

Keywords: Heavy metals, Risk assessment, Human healt, European eel, Lake Köyceğiz, Lake Võrtsjärv

Posted Date: April 28th, 2021

DOl: https://doi.org/10.21203/rs.3.rs-421925/v1

License: (c) (i) This work is licensed under a Creative Commons Attribution 4.0 International License. Read Full License 


\title{
Bioaccumulation of metals in eels taken from Lakes Köyceğiz (Turkey) and Võrtsjärv (Estonia) and
} health risk assessments

\author{
Ahmet Demirak ${ }^{1 *}$, Feyyaz Keskin ${ }^{2}$, Maidu Silm ${ }^{4,5}$, Nedim Özdemir ${ }^{3}$, Dilek Yıldız ${ }^{2}$, Priit Bernotas ${ }^{4,5}$, Burak
} Öğlü̆,5 ${ }^{I}$ Mugla Sitki Kocman University, Faculty of Science, Department of Chemistry, Mugla, Turkey

${ }^{2}$ Mugla Sttka Kocman University, Environmental Problems Research and Application Center, Mugla, Turkey

${ }^{3}$ Mugla Sitkı Kocman University, Aquaculture Faculty, 48000 Mugla, Turkey.

${ }^{4}$ Chair of Hydrobiology and Fishery, Institute of Agricultural and Environmental Sciences, Estonian University of Life Sciences, Kreutzwaldi 5, 51006 Tartu, Estonia.

${ }^{5}$ Estonian Marine Institute, University of Tartu, Mäealuse 14, Tallinn 12618, Estonia

*Corresponding author: ademirak@yahoo.com; ademirak@ mu.edu.tr, (Dhttps://orcid.org/0000-0002-6815-8037

Abstract Monitoring heavy metal contaminants in fish is important for the assessment of environmental quality as well as food safety. In this study, European eel samples were collected from Lake Köyceğiz and Lake Võrtsjärv in 2017 and 2018. The concentrations of $\mathrm{Mn}, \mathrm{Cd}, \mathrm{Zn}, \mathrm{Pb}$, and $\mathrm{Cu}$ metals were measured by using GFAAS in four selected tissues of eel, including liver, gill, skin, and muscle in both lakes. The pollution indexes $\left(\mathrm{P}_{\mathrm{i}}, \mathrm{MPI}\right)$ values were calculated for both lakes and the health risk for consumers was assessed for both adults and children in Turkey and Estonia. The estimated weekly intake (EWI), hazard index (HI), and lifetime cancer risk values (CRs) for the metals were calculated for both lakes. According to the results of this study, a significant difference was determined the between the metal concentrations (especially $\mathrm{Cu}, \mathrm{Cd}$ and $\mathrm{Pb}$ ) in the tissues of the eel samples taken from the two lakes. These results show that besides the pollution levels in the aquatic environment, physiological needs, and metabolic activities in different habitats have a significant effect on metal accumulation in eels. In addition, HI was found to be $<1$ for both adult and child consumers in both lakes, which indicates that consumers would not experience non-carcinogenic health effects. However, the values of $\mathrm{CR}$ for $\mathrm{Pb}$ and $\mathrm{Cd}$ were found negligible in Lake Köyceğiz, while the $\mathrm{CR}$ value for $\mathrm{Pb}$ was found to be very close to the danger limits in Lake Võrtsjärv.

Keywords: Heavy metals. Risk assessment. Human healt. European eel. Lake Köyceğiz. Lake Võrtsjärv Introduction

Fish is one of the main food sources containing a large number of essential proteins and nutrients in high concentrations that can be easily absorbed and digested by humans. Although, protein and essential nutrients are extremely necessary for the human body, fish is considered one of the inexpensive sources of protein and essential nutrients for consumption (FAO 2008). However, fish, which are at the top of the food chain in aquatic ecosystems, are highly affected by heavy metal (HM) pollution from many different sources and as a result heavy metals can accumulate in their bodies in the aquatic environments. Therefore, fish can be considered as one of the most serious sources of metals affecting human health (Miao et al. 2020; Zerizghi et al. 2020). It is known that the HM contamination in fish is extremely important in terms of consumer awareness and safety. 
HMs are known as the most important environmental pollution indicators. They tend to bioaccumulate and remain in food for a long time (Ahmed et al. 2019).

European eels are used as a reliable biological indicator in the investigation of HM pollution in aquatic ecosystems, as they are a migratory and predatory species, especially because of their longevity and benthic lifestyle (Lortholarie et al. 2019; Pannetier et al. 2016). They have been proposed as a suitable matrix for biological monitoring of environmental pollutants in European freshwater bodies in accordance with the 2000/60/ EC Water Framework Directive (WFD) (EC 2000; Belpaire and Goemans 2007). The pollutant concentrations (especially those with low water solubility) in the tissues of eels, which have a complex life cycle, represent a combination of environmental pollution, together with the pollution loads of the species, surface waters, and sediments in aquatic ecosystems. Inorganic pollutants such as HMs may play a role in the decline of European eels (Belpaire et al. 2019; Romero et al. 2020; Pannetier et al. 2016; Juszczak et al. 2015). Given their unique life cycle, European eels are particularly vulnerable to inorganic pollution (Geeraerts and Belpaire 2010). Due to the high lipid content of eels, metals in organometallic form accumulate more in their tissues (Byer et al. 2015; Freese et al. 2016; Chiesa et al. 2019). Previous studies indicated that eels accumulate more amounts of metals than other fish species (Pannetier et al. 2016). The bioaccumalation of metals in eels can have an effect on their life cycle. Because metals accumulated during the yellow stage of eels can be reactivated during reproductive migration, they can interfere with movement and gonad maturation and cause toxicity events in the embryonic stage (Usero et al. 2003; Durrieu et al. 2005; Pannetier et al. 2016). Most of these pollutants, which are usually persistent organic chemicals and HMs, are considered carcinogenic and some of them are stated to impair metabolic and endocrine functions in humans. Consequently, the consumption of eels is a mark that humans are directly exposed to these pollutants (Juszcak et al. 2015; Maes et al. 2008; Eira et al. 2009). Because they are an edible species with high economic value and are important for both recreational and commercial fisheries, their contamination represents a potential public health problem, as they are consumed in large quantities in Europe. However, eel consumption in Turkey is considerably low compared to Europe. Metal pollution in the water ecosystem in Lake Köycegiz (LK) arises usually from agriculture, tourism, and fishing activities. In Lake Võrtsjärv (LV), on the other hand, domestic and agricultural pollution prevails. Eel population in LV relies on an annual restocking program (Bernotas et al. 2016), while Köyceğiz Dalyan Lagoon System is a transit route for Eel. In this way, eels migrate from LK to the Mediterranean.

In this study, the concentrations of $\mathrm{Cd}, \mathrm{Cu}, \mathrm{Mn}, \mathrm{Pb}$, and $\mathrm{Zn}$ in tissues (muscle, liver, gills, and skin) were determined in European eel caught from LK and LV. LK is one of the key areas for the tourism and fisheries sector in Turkey and LV is one of the most important inland commercial/reacreational fisheries zone and the second-largest lake in Estonia. LK is located in the Köyceğiz-Dalyan Lagoon System, which is declared a Special Environmental Protection Area due to its ecological importance and natural beauties (Özdemir 1998). The eels in LK are naturally found and can migrate by maintaining their completely natural life. While being restocked, eels perform migrations from LV as well. Besides the annual seaward silver eel migration through the Narva River Basin, eels also use rivers to move between lakes of the aforementioned river basin district. The aims of this study, which is carried out considering these different life cycles of the same species, are;

1. To determine the pollution levels by detecting HM concentrations in the tissues of eel taken from both lakes, 2. To evaluate the effect of two different habitats on metal accumulation in tissues of eels, 
3. To examine the effect of contaminant sources (agricultural, domestic, etc.) and biological factors (height, weight, etc.) on metal accumulation in tissues of eels,

4. To evaluate the effects of eels with high economic value on human health in two countries with different consumption habits.

\section{Material and methods}

The study area

$\mathrm{LV}$, a shallow large lake (long-term average depth of $2.7 \mathrm{~m}$, maximum depth of $6 \mathrm{~m}, 34.8 \mathrm{~km}$ in length, $14.8 \mathrm{~km}$ in width, and $270 \mathrm{~km}^{2}$ in surface area) is located in the center of Estonia (Fig 1). Low depth and large surface area make LV sensitive to environmental changes. Also, the lake is covered with ice from midNovember to April (Bernotas et al. 2020; Haberman et al. 1998). The main cultivated drainage area exceeds the lake area by about 12 times. LV has five important inflows and an outflow that discharges into Lake Peipsi via the Emajõgi River. Due to a limited outflow, changes in water level have large seasonal and year-varying amplitudes (Nõges et al. 2007). Although LV is used for fishing, recreation and tourism activities, it is also used for irrigation of cultivable lands below sea level (Haberman et al. 1998). According to the typology of the Water Framework Directive, VK is a large, calcareous shallow lake and almost all ecological level parameters of the lake fall into the "good" or "middle" class (Bernotas et al. 2020). 31 fish species live permanently in LV. Eel, perch (Sander lucioperca), pike (Esox lucius), perch (Perca fluviatilis), and sea bream (Abramis brama) are the most important commercial species in the lake. Eel production in LV is based entirely on a restocking of glass eel or elvers. The restocking program started in 1956 and continues to this day, and since 1980, eel stocking has been carried out annually (Bernotas et al. 2020). LV has its own fisheries district, under which over 50 fishermen/companies operate. The most common fishing gears used are fyke- and gill nets. Fyke net fishing is allowed around the year while gill nets are only allowed from September until the end of ice-cover period (Nõges et al. 2018).

LK is located in the south-west of Turkey within the boundaries of Muğla Province. It lies within $36^{\circ} 54^{\prime}$ $\mathrm{N}$ and $28^{\circ} 38^{\prime} \mathrm{E}$ longitude coordinates. It has a 5400 ha surface area and a $14 \mathrm{~km}$ long Dalyan canal system connects LK to the sea with natural water channel (Fig. 1, ArcGIS 10.3) (Bayarı ve Kurttaş 2000).

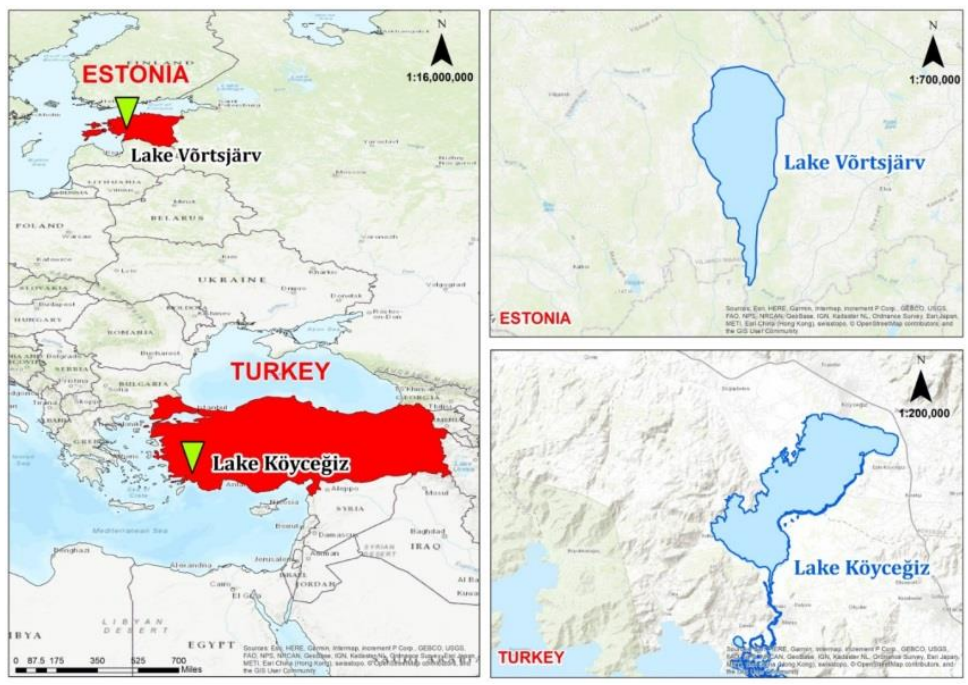


Fig. 1 The map of the study area

All of the canals and marshy areas connecting LK to the sea are called the Köyceğiz-Dalyan Lagoon System and the lake forms the main part of this system. It is a meromictic lake with two different layers of water as oxygen-poor, hydrogen sulfide-scented, salty water in the bottom and oxygen-rich, freshwater at the surface (Kazanc1 et al. 2003). The physico-chemical structure of the lake is constantly changing and these changes occur depending on the activity of groundwater. Groundwater is affected by domestic wastes, fertilization, and spraying on the agricultural lands in the region. Also, the water quality of all streams flowing into the lake changes due to various reasons such as precipitation, aridness, and discharge of domestic wastewater to streams and fertilization and spraying in the region. These pollution factors carried by groundwater and streams directly interfere with the lake and cause changes in the physico-chemical structure of the lake. However, there is a pollution pressure due to heavy boat traffic especially during the summer season (Özgül 2014). There are 5 different hydro-chemical water types affecting LK (groundwaters, streams, hot springs, lakes, and seawater). For this reason, the water of LK is classified in some regions as fresh water, and in some others as salty water, or brackish water (Gürel 2004). The type of cryogenic meromixis caused by salty and sulfurous water sources on the lake bottom also affects the current structure of the lake (Türedi 2006). The greatest richness of the Köyceğiz Dalyan Lagoon System in terms of fauna is mainly mullet, eel, sea bass, sea bream, and carp fish species, and their production is an important commercial activity for the region. Commercial fishing is done by fishing cooperative (DALKO), but recreational fishing is also allowed in the lake.

Sample collection

For this study, samples were collected from both lakes in September, 2017 and 2018. Eel samples were caught using an enclosure fyke net system in LV (Ubl and Dorow 2015). The system consists of 4 corner chambers (mesh size $10 \mathrm{~mm}$ in cod end) connected by $100 \mathrm{~m}$ leader nets (height $1.8 \mathrm{~m}$, mesh size $10 \mathrm{~mm}$ ) forming a rectangle in the water body. 24 small fyke nets ( 2 funnels connected with $8 \mathrm{~m}$ leaders with mesh size $11 \mathrm{~mm}$ in the cod end) are set in chains inside the rectangle. In LK, eel samples were taken by the fishermen of DALKO with fyke nets consisting of 7 circles whose mouth width narrowed from $40 \mathrm{~cm}$ to $15 \mathrm{~cm}$. Fyke nets were thrown into the water after sunset and eels were caught by pulling before sunrise.

Sample preparation and analysis

A total of 40 eels in LV were collected in 2017 and 2018. The collected eel samples were transported to the laboratory on the same day. Eel samples were thoroughly washed with milli-Q water (Milli-Pore Co., USA; resistivity, 18.2 M $\Omega-\mathrm{cm}$ ). Then they were dissected (muscle, liver, gills, skin) and the tissues were stored immediately at $-20^{\circ} \mathrm{C}$. All chemicals were of analytical reagent grade and were provided by Merck (Darmstadt, Germany). Standard solutions of $\mathrm{Cd}, \mathrm{Mn}, \mathrm{Zn}, \mathrm{Pb}$, and $\mathrm{Cu}$ were prepared by making necessary dilutions from their stock standard solutions: $1000 \mathrm{mgL}^{-1} \mathrm{Cd}, \mathrm{Mn}, \mathrm{Zn}, \mathrm{Pb}$, and $\mathrm{Cu}$.

The tissues were dried to a constant weight for $48 \mathrm{~h}$ at $45{ }^{\circ} \mathrm{C}$. Dried samples were homogenized by grinding in a porcelain mortar and then stored in a desiccator for metal analysis. $0.2 \mathrm{~g}$ dry weight of each homogenate tissue was transferred into a teflon vessel and then digested using closed-vessel microwave digestion (CEM, Mars 6) with $9 \mathrm{~mL}$ nitric acid (65\%) and $1 \mathrm{~mL}$ hydrogen peroxide (30\%) mixture. The resulting solutions were diluted to $50 \mathrm{~mL}$ with deionized water. Digestion blanks were prepared similarly. The microwave 
was programmed to ramp to $210{ }^{\circ} \mathrm{C}$ for $20 \mathrm{~min}$, hold for $15 \mathrm{~min}$, and then cool for $20 \mathrm{~min}$. $\mathrm{Cd}, \mathrm{Mn}, \mathrm{Zn}, \mathrm{Pb}$, and $\mathrm{Cu}$ metals in dissolved fish samples were analyzed by graphite furnace atomic absorption spectrometer (GFAAS) Agilent GTA 120 (Agilent Technologies Company, USA) with argon gas (99.9999 \%). All measurements for the metals were run in triplicate for the samples and standard solutions and the results were reported as the mean. Also, the accuracy of the method was checked with standard reference material (DOLT-5 fish liver).

Statistical analysis

To analyze the normality of the data, the Shapiro-Wilk test was applied. To detect the difference in metal concentration among the countries and tissues of the European eel, non-parametric test Kruskal Wallis and Post hoc test that using the criterium Fisher's least significant difference with Bonferroni Correction method were performed by using Kruskal function with the R package 'agricolae' (Mendiburu 2020). Statistical differences were illustrated on the box plot graphs. In addition, spearman correlation analysis was applied to assess the statistical assosiations between metal in different organs, fish length and weight. $\mathrm{R}$ project 4.0.2 was used for statistical procedures (R Core Team 2020).

Assessment of metal pollution

The monomial metal pollution index $\left(\mathrm{P}_{\mathrm{i}}\right)$ was used in this study to evaluate the pollution status of metals in the eels. $P_{\mathrm{i}}$ was calculated by using the following Eq. 1 (Zhu et al. 2015; Miao et al. 2020):

$P_{i}={ }^{C_{i}} / C_{s i}$

Where: $\mathrm{P}_{\mathrm{i}}$ : monomial metal pollution index; $\mathrm{C}_{\mathrm{i}}$ : content of metal in the fish; $\mathrm{C}_{\mathrm{si}}$ : threshold value of metal in the fish. In this study, the tolerable limit values of the $\mathrm{Pb}$ and $\mathrm{Cd}$ as prescribed by some international regulatory bodies were used as the threshold values of $\mathrm{Pb}$ and $\mathrm{Cd}$ (Table 1).

Table 1 The tolerable values of some HMs in fish $\left(\mathrm{mg} \mathrm{kg}^{-1}\right)($ Kortei et al. 2020)

\begin{tabular}{|c|c|c|}
\hline Organization & $\mathrm{Cd}$ & $\mathrm{Pb}$ \\
\hline $\mathrm{UNEP}^{\mathrm{a}}$ & 0.3 & 0.3 \\
\hline IAEA- $407^{\mathrm{b}}$ & 0.18 & 0.12 \\
\hline $\mathrm{TFC}^{\mathrm{c}}$ & 0.05 & 0.2 \\
\hline Directive $2005 / 78 / \mathrm{EC}^{\mathrm{d}}$ & 0.05 & 0.2 \\
\hline $\mathrm{FAO} / \mathrm{WHO}^{\mathrm{e}}$ & 0.5 & 0.5 \\
\hline
\end{tabular}

According to many studies; four classes have been identified for the $P_{i}: P_{i}<0.2$ : no significant contamination; $0.2<\mathrm{P}_{\mathrm{i}}<0.6$ : minor contamination; $0.6<\mathrm{P}_{\mathrm{i}}<1$ : moderate contamination, and $\mathrm{P}_{\mathrm{i}}>1$ : high contamination. In previous studies: the total metal pollution index (MPI) has been used to compare the overall differences in metal pollution observed among the different wild fish species caught by fishermen (Yang et al. 2013; Miao et. al. 2020). Metal pollution index was used for eel inhabiting both lakes. The calculation of MPI was as follows:

$$
M P I=\left(C_{1} \times C_{2} \ldots C_{n}\right)^{1 / n}
$$


where $\mathrm{C}_{\mathrm{n}}$ is the concentration of metal $\mathrm{n}$ in fish.

Health risk estimation

To estimate possible health risks for consumer concerning European eel in LK and LV, the values of EDI,

174

175

176

177

178

179

180

181

182

183

184

185

186

187

188

189

190

191

192

193

194

195

196

197

198

199

200

201

202

203

THQ, and CR were calculated for four different frequencies. In many studies, they are calculated taking into account the consumption frequencies of seven times a week to estimate health risks for fish. But it can be assumed that due to its high price, eel is not consumed that often in either Estonia or Turkey. For this reason, health risk indices were calculated on the assumption of consuming eel once a month. The values of EDI, Target hazard quotient (THQ), HI, and CR were calculated separately for both child and adult consumers. According to the data obtained by EPA (2000), the mean body weight of $70 \mathrm{~kg}$, and lifetime of 70 years for adults were considered while for children these values were $32 \mathrm{~kg}$ (EPA 2008), and 7 years respectively. The values of EDI, THQ, HI, and CR were calculated by using assumptions in the formulas below.

Estimation of daily intake (EDI)

Preliminarily, the prediction of human health hazards stems from the consumption of metals in foodstuffs (Traina et al. 2019; Ahmed et al. 2019). For this purpose, EDI is evaluated depending on the metal concentration level in foods and the daily consumption of foods at the same time (Batista et al. 2012; Kosker 2020). The values of EDI were calculated using the Eq. 3 below (EPA 2000).

$E D I=\left(C_{M} \times I R_{d}\right) / B W$

In EDI calculations, $C_{M}$ is the concentration of the metal in muscle ( $\mu \mathrm{g} \mathrm{g}^{-1}$ dry weight basis), $\mathrm{IR}_{\mathrm{d}}$ is the daily ingestion rate $\left(\mathrm{g} \mathrm{day}^{-1}\right)$ derived from the EUROFISH International Organization (2017) based on European eel production in Estonia and Turkey. According to these data, consumption of eel in Turkey and Estonia was calculated as 0.002 gperson $^{-1} \mathrm{day}^{-1}$ and $0.265 \mathrm{~g}^{-} \operatorname{erson}^{-1} \mathrm{day}^{-1}$, respectively. We estimated for children an $\mathrm{IR}_{\mathrm{d}}$ equal to $40 \%$ of the $\mathrm{IR}_{\mathrm{d}}$ for adults $\left(8.10^{-4}\right.$ gperson $^{-1}$ day $^{-1}$ in Turkey, $0.106 \mathrm{~g}^{-}$person ${ }^{-1} \mathrm{day}^{-1}$ in Estonia for children). BW is the bodyweight of adults and children (adult $70 \mathrm{~kg}$; children $32 \mathrm{~kg}$ ) (EPA 2008).

\section{Target hazard quotient (THQ)}

THQ value is used for the determination of non-carcinogenic risk level of exposure to contaminants. THQ is defined as the expression of the ratio between the reference dose (RfD) of metals and the exposure rate. THQ value was calculated using the Eq. 4 below (EPA 2019);

$T H Q=\left[(E F x E D x E D I) /(R f D x A T) \times 10^{-3}\right.$

In Eq. 4, EF is the exposure frequency (365, days year ${ }^{-1}$ for people who eat fish seven times a week, 156 days year $^{-1}$ for people who eat fish three times a week, 52 days year-1 $^{-1}$ for people who eat fish once a week, and 12 days year ${ }^{-1}$ for people who eat fish once a month), ED is the exposure duration (adults 70 years, children 7 years); $\mathrm{EDI}$ indicates the estimation of daily intake (equation 3), RfD represents the oral reference dose in $\mu \mathrm{g} \mathrm{g}^{-}$ ${ }^{1}$ day $^{-1}: \mathrm{Cu}=0.03, \mathrm{Zn}=0.3, \mathrm{Mn}=0.14, \mathrm{Cd}=1.10^{-3}, \mathrm{~Pb}=4.10^{-3}$ (EPA, 2019). AT indicates the average time for non- 
carcinogens (EF x ED). AT indicates the average time forcarcinogens (365 days year-1 $\mathrm{x} 70$ ). Although the THQ does not give information on quantitative health risks for people who are exposed, it indicates the potential hazard associated with exposure to certain pollutants. The values of THQ higher than 1 indicate a significant health risk arising from the intake of individual metals through fish consumption, assuming that cooking does not affect contaminants.

Hazard Index $(H I)$

Humans are often exposed to multiple pollutants that have combined or interactive effects. When exposed to different elements, $\mathrm{HI}$ is calculated according to the Eq. 5 given below to evaluate the additive effects from the elements.

$$
H I=\sum_{i}^{n} T H Q
$$

HI values being > 1 refers that consumers may be exposed to possible non-carcinogenic health risk effects.

\section{The lifetime carcinogenic risk (CR)}

The lifetime CR identifies an increased probability of cancer in a lifelong period due to exposure to a major carcinogen. The acceptable limit value for $\mathrm{CR}$ exposure is $10^{-6}$ to $10^{-4}$. CR values $>10^{-4}$ affect (increase) the possibility of carcinogenic risk. CR was calculated according to the Eq. 6 given below.

$$
C R=(E F x E D x E D I x C S F / A T) \times 10^{-3}
$$

In equation 6, CSF represents the oral carcinogenic slope factor from the Integrated Risk Information System in $\mathrm{mg} / \mathrm{kg} / \mathrm{day}: \mathrm{Cd}=6.3, \mathrm{~Pb}=8.5 \cdot 10^{-3}$ (EPA, 2019). The acceptable limit value for $\mathrm{CR}$ is $10^{-5}$.

\section{Results and discussion}

Presence and comparison of the metals found in European eel in two lakes

Many fish species are negatively affected by increasing anthropogenic pressures, climate changes due to global warming, water pollution, overfhishing and recreational fisheries and habitat degradation (Bernotas et al. 2020; Pannetier et al. 2016; Romero et al. 2020; Lortholarie et al. 2019; Öğlü et al. 2020). Eel, which is a benthic species and lives in different habitats, is one of such species. Eel is a species with high commercial value and is widely consumed in Europe and its stocks have been decreasing for the last 30-40 years due to the reasons mentioned above (Dekker 2016). Eel consumption in Turkey is low compared to other species; however, eel is exported since it has a high economic value. Köycegiz-Dalyan Lagoon System is one of the most important habitats of eel in Turkey. LK, located in the Köyceğiz -Dalyan Lagoon System, is especially salty in the deep waters and is connected to the Mediterranean by a natural channel system. Therefore, eel can freely move in and out, thus restocking the eel is not considered in LK.

The concentrations of $\mathrm{Cu}, \mathrm{Mn}$, and $\mathrm{Zn}$ as micronutrients and $\mathrm{Cd}$ and $\mathrm{Pb}$ as toxic metals were measured in the liver, muscle, gill, and skin of eels caught from LK and LV in 2017-2018. The average weight and length of the measured eels in LK and LV 1 were $366 \pm 113 \mathrm{~g}, 548 \pm 72 \mathrm{~mm}$, and $247 \pm 97 \mathrm{~g}, 505 \pm 73 \mathrm{~mm}$, respectively. While the mean length of the eels in both lakes was close to each other, the weight of the eels taken from LK 
was determined heavier than from LV. On the other hand, in this study, significant differences were observed between the average HM concentrations determined for eels caught from LK and LV. The weights of eels have the potential to affect HM concentrations in their tissues (Pannetier et al. 2016). According to the weight data of the fish, while the eel tissues in LK are expected to be higher, the results obtained are inverse. The accumulation of the HM in tissues of eels is thought to be influenced by environmental and other factors in both lakes. While the eels in LK have also the ability to move between environments with different salinity regimes, the movements of the eels in LV are restricted. In addition, while the eels in LV have feed in one habitat, the eels in LK have feed in two different habitats. The accumulation of essential metals $(\mathrm{Mn}, \mathrm{Cu}$, and $\mathrm{Zn})$ in eel was found higher than the accumulation of non-essential metals $(\mathrm{Cd}$ and $\mathrm{Pb})$ in both lakes. These results of the study can also be explained by the fact that essential metals play a role in enzymatic and respiratory processes and have structural and catalytic roles in many proteins, acting as cofactors in many enzymatic reactions in fish, these metals play a vital role in lipid, protein, and carbohydrate metabolism (Pouil et al. 2020). Although many studies have proven that trace element accumulation in aquatic organisms depends on biological and ecological factors such as dietary habits and habitat (Henry et al. 2004; Sankar et al. 2006; Kojadinovic et al. 2007; Dehkordi et al. 2010), the concentration of metals is also affected by factors other than these factors (Maes et al. 2008; Pannetier et al 2016). The concentrations of $\mathrm{Zn}$ and $\mathrm{Cu}$ in the liver of fish may be associated with metallothionine synthesis and may not be associated with the metal concentrations in the fish's habitat (Batty et al. 1996). Non-essential metals such as $\mathrm{Cd}$ and $\mathrm{Pb}$ do not have any role to play in fish metabolism and they are not regulated by the organism of fish (Aytekin et al. 2019).

Fish take up HMs by way of the food chain and water containing dissolved HMs (Pierron et al., 2008). Therefore, they can accumulate metals in different tissues with biochemical processes. In many studies, the tissues with the highest metal accumulation in fish have been determined as liver and kidneys (Pannetier et al. 2016; Genç and Yılmaz 2017; Eira et al. 2009). As a result of the enrichment of HMs in the tissues, negative effects on human health can be observed after consuming contaminated fish (Aytekin et al. 2019; Miao et al. 2020). The liver and gills which are inconsumable by humans are metabolically active tissues and they have a high level of HM accumulation. In this study, the concentration orders of HMs in the tissues of the eels were generally found to be liver > gills > skin > muscle in both lakes, and the highest HM concentrations were detected in the liver and the lowest concentrations in the muscle (Table 2). These results are found similar to the previous studies. The acuumulation of $\mathrm{Zn}$ in all tissues of eels except liver was determined as the highest while the accumulation of $\mathrm{Cd}$ and $\mathrm{Pb}$ in all tissues of eels was found as the least.

Table 2 Average concentrations of HMs (mean $\pm \mathrm{SD} \mu \mathrm{g} \mathrm{g}{ }^{-1}$ dry wt) in the tissues

\begin{tabular}{cccc}
\hline Metals & Tissues & Lake Köyceğiz & Lake Võrtsjärv \\
\hline \multirow{3}{*}{$\mathrm{Mn}$} & Muscle & $0.47 \pm 0.19$ & $2.66 \pm 1.90$ \\
& Liver & $5.57 \pm 3.10$ & $4.31 \pm 3.37$ \\
& Skin & $3.08 \pm 1.26$ & $4.78 \pm 1.71$ \\
& Gill & $4.45 \pm 0.86$ & $4.39 \pm 3.35$ \\
\hline \multirow{3}{*}{$\mathrm{Cd}$} & Muscle & $0.06 \pm 0.05$ & $0.09 \pm 0.06$ \\
& Liver & $0.40 \pm 0.28$ & $0.19 \pm 0.09$ \\
& Skin & $0.28 \pm 0.18$ & $0.21 \pm 0.18$ \\
& Gill & $0.28 \pm 0.21$ & $0.12 \pm 0.07$ \\
\hline \multirow{3}{*}{$\mathrm{Zn}$} & Muscle & $2.96 \pm 0.66$ & $3.94 \pm 2.52$ \\
& Liver & $7.34 \pm 4.48$ & $7.81 \pm 5.68$ \\
& Skin & $4.13 \pm 1.44$ & $5.14 \pm 3.38$ \\
& Gill & $4.65 \pm 1.84$ & $8.57 \pm 6.60$ \\
\hline $\mathrm{Pb}$ & Muscle & $0.24 \pm 0.05$ & $0.82 \pm 0.50$
\end{tabular}




\begin{tabular}{cccc} 
& Liver & $0.28 \pm 0.10$ & $0.85 \pm 0.64$ \\
& Skin & $0.13 \pm 0.08$ & $0.61 \pm 0.32$ \\
& Gill & $0.33 \pm 0.19$ & $0.85 \pm 1.14$ \\
\hline \multirow{3}{*}{$\mathrm{Cu}$} & Muscle & $1.75 \pm 0.73$ & $0.97 \pm 0.60$ \\
& Liver & $15.23 \pm 1.45$ & $13.35 \pm 4.87$ \\
& Skin & $2.06 \pm 0.70$ & $1.88 \pm 1.45$ \\
& Gill & $3.10 \pm 0.88$ & $2.37 \pm 0.46$ \\
\hline
\end{tabular}

A significant difference was found between the concentrations of $\mathrm{Cd}, \mathrm{Cu}$, and $\mathrm{Pb}$ in all tissues of eel in both lakes (Fig. 2). On the other hand, it was determined that Mn concentrations showed a significant difference between the two lakes in the liver and skin, but not in gill and muscle tissues ( $p>0.05)$. However, it was determined that the concentration of $\mathrm{Zn}$ in all tissues did not show a significant difference between the two lakes.
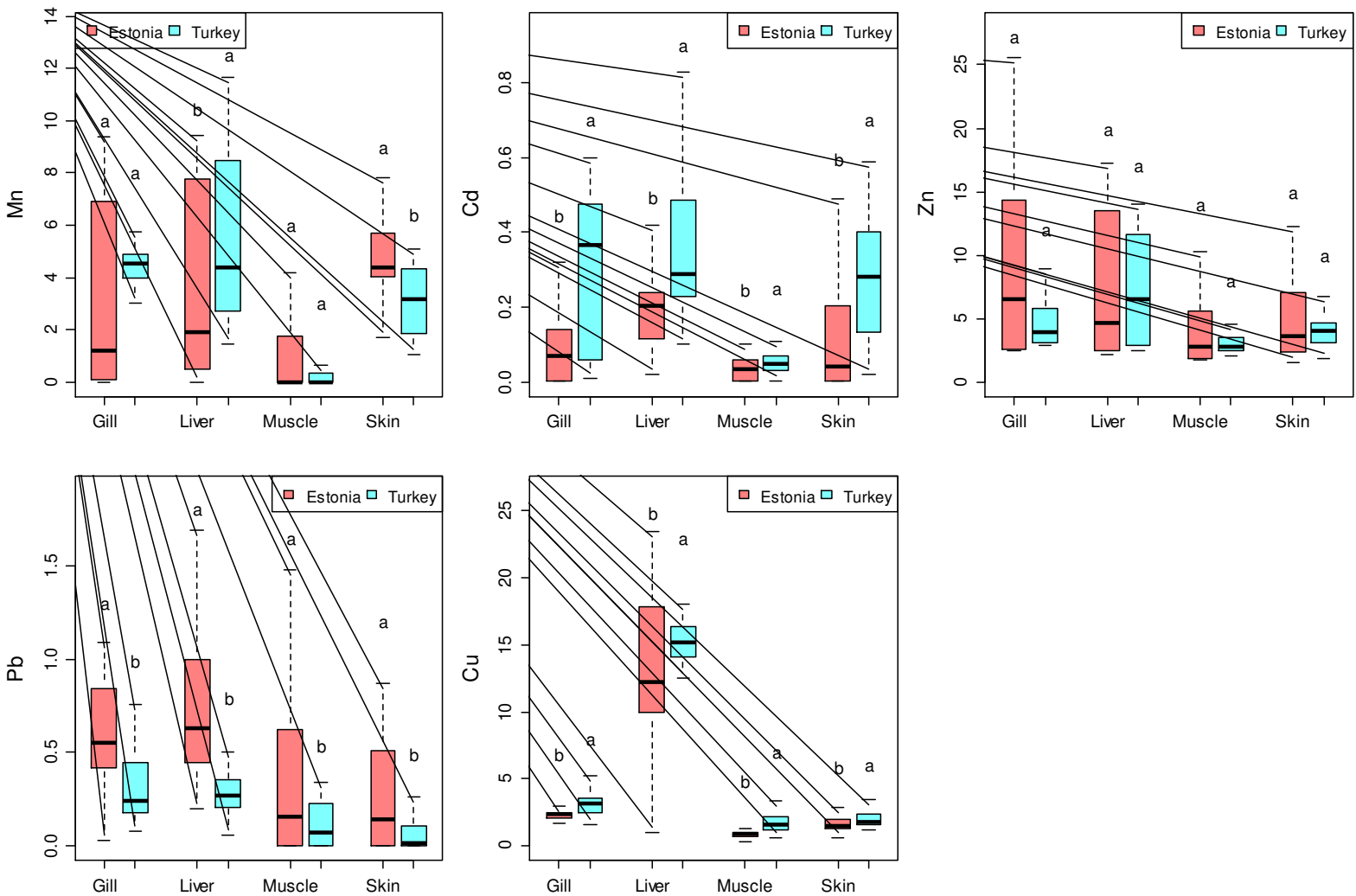

Fig 2. Boxplot comparison of HM concentrations in tissues of the eel

The dark line within the box indicates the $50^{\text {th }}$ percentile of the data. Whiskers are indicating maximum and minimum data points (excluding outliers). Letters ( $a, b)$ are indicating the comparison between the two lakes within the same tissue. The highest HM concentrations were detected in the liver and the lowest HM concentrations in the muscle of eels from both lakes. The highest concentration of $\mathrm{Zn}$ was measured in muscle, skin, and gill, and the highest $\mathrm{Cu}$ in the liver (Table 3). The liver is one of the organs that represent the main sites of metal storage and detoxification (Pannetier et al. 2016). Several studies have shown that liver HM concentration is high compared to muscle tissue (Pannetier et al. 2016; Aytekin et al. 2019; Miao et al. 2020). Table 3 shows the distribution of HM concentrations in tissues of the eels determined in both lakes.

Table 3 Ranking of HM concentrations in tissues of the eel
Tissues
Lake Köyceğiz
Lake Võrtsjärv 


\begin{tabular}{lll}
\hline Muscle & $\mathrm{Zn}>\mathrm{Cu}>\mathrm{Mn}>\mathrm{Pb}>\mathrm{Cd}$ & $\mathrm{Zn}>\mathrm{Mn}>\mathrm{Cu}>\mathrm{Pb}>\mathrm{Cd}$ \\
Liver & $\mathrm{Cu}>\mathrm{Zn}>\mathrm{Mn}>\mathrm{Cd}>\mathrm{Pb}$ & $\mathrm{Cu}>\mathrm{Zn}>\mathrm{Mn}>\mathrm{Pb}>\mathrm{Cd}$ \\
Skin & $\mathrm{Zn}>\mathrm{Mn}>\mathrm{Cu}>\mathrm{Cd}>\mathrm{Pb}$ & $\mathrm{Zn}>\mathrm{Mn}>\mathrm{Cu}>\mathrm{Pb}>\mathrm{Cd}$ \\
Gill & $\mathrm{Zn}>\mathrm{Mn}>\mathrm{Cu}>\mathrm{Pb}>\mathrm{Cd}$ & $\mathrm{Zn}>\mathrm{Mn}>\mathrm{Cu}>\mathrm{Pb}>\mathrm{Cd}$ \\
\hline
\end{tabular}

The concentrations of $\mathrm{Cu}$ in the liver of eel were measured higher than the other metals in both lakes. On the other hand, the mean $\mathrm{Cu}$ concentrations in all the tissues of eels in LK were found higher than the concentrations in LV. Many studies have shown that the high concentration of $\mathrm{Cu}$ in fish is due to agricultural activities (Pannetier et al. 2016). The results of this study may show that there is agricultural contamination in LK.

The concentrations of $\mathrm{Zn}$ in all tissue of eel samples in both lakes were measured the highest, except the liver. Many previous studies have found similar results of $\mathrm{Zn}$ concentration in different fish species in many different geographies (Topçuoğlu et al. 2002; Sekhar et al. 2004; Sivaperumal et al. 2007; Kojadinovic et al. 2007; Mata et al. 2020). Zn may enter the studied lakes through agriculture or various industries however the rather low $\mathrm{Zn}$ concentrations observed in the livers of collected eels indicate low presence of $\mathrm{Zn}$ in both water bodies.

$\mathrm{Mn}$ is an essential micronutrient for fish, but it can be a very toxic metal for fish at concentrations above the optimum threshold level. However, it is an element that has not been investigated sufficiently in aquatic ecosystems. The Mn concentration range that causes toxicity depends on the fish species, life cycle, and the water quality of the environment (Vieira et al. 2012). In this study, the concentrations of Mn in muscle and skin tissues of eel in LV were higher than in LK, the average Mn concentrations in the gill tissue of eel were the same in both lakes, and the concentrations of Mn in the liver tissue of eel in LK were found higher than in LV (Table 2). The reason for these differences for $\mathrm{Mn}$ is thought to be the physiology of the fish and the conditions of the environment in which the eels live. It is stated that salinity in aquatic ecosystems is one of the most important factors affecting the accumulation of metals such as Cd, Zn, and Mn in fish (Pouil et al. 2020; Nebel et al. 2013, Neto et al. 2011). It could be that the difference in salinity in both lakes (salinity, LK>LV) affects the Mn accumulation in the tissues of eel. It has been determined that the accumulation of Mn concentration in turbot (Scophthalmus maximus) decreases with increasing salinity (Pouil et al. 2020).

Bioaccumulation of toxic metals in eels has a significant impact on its physiology. The high toxic metals such as $\mathrm{Cd}, \mathrm{Pb}$, and $\mathrm{Hg}$ can impair the immune, reproductive, nervous, and endocrine systems, thus negatively affecting cellular and organ functions at the individual and even population level (Romero et al. 2020; Claveau et al. 2015; Pierron et al. 2008; Riberio et al. 2005). The concentrations of Cd in the liver, gill, and skin tissues of eel from both lakes were measured approximately 10 times higher than the concentrations of $\mathrm{Cd}$ in the muscle (Table 2). Generally, the concentrations of $\mathrm{Cd}$ in European eels were observed higher in liver and kidney than other tissues (Lanceleur et al. 2011). Also, the average $\mathrm{Pb}$ concentrations in all the tissues of eels in LV were measured higher than the average $\mathrm{Pb}$ concentrations in $\mathrm{LK}$. In both lakes, lead $\mathrm{Pb}$ accumulation was determined smallest in the skin (Table 2). In eels, the accumulation of $\mathrm{Pb}$ in tissues can be increased both by its association with detoxified subcellular fractions such as granules and heat-resistant proteins and by the presence of metalsensitive fraction-containing contaminants (such as organometallic compounds) in the aquatic environment. The 
differences of the bioaccumulation of toxic metals in fish muscle tissues is due to several factors such as feeding

319 habits, environmental conditions, habitats, exposure time and trophic levels, as well as fish body length, weight, age, phenotypic differences, gender, physiological conditions, developmental stage, metabolism (Jia et al. 2017;

321 Carrasco et al. 2011; Mata et al. 2020). In this study, the difference in $\mathrm{Pb}$ concentration determined in the muscles of eels in both lakes is thought to be caused by environmental conditions and feeding habits.

The relationship between metal concentrations in tissues and height and weight of eel

324 Spearman correlation matrix is given in Table 4. A strong negative correlation between length and weight values

325 and concentration of $\mathrm{Zn}, \mathrm{Mn}$, and $\mathrm{Pb}$ in all tissues, a positive correlation with concentration of $\mathrm{Cd}$ in all tissues, especially a strong positive correlation with $\mathrm{Cd}$ concentrations in gills and skin were determined. Weak correlations were found between $\mathrm{Cu}$ concentrations in different tissues and length and weight. Besides, it was found that there was a positive correlation between the concentrations of $\mathrm{Zn}$ and $\mathrm{Pb}$ in all tissues, but a negative correlation with the $\mathrm{Cd}$ concentrations. A positive correlation was found between concentrations of $\mathrm{Cd}$ in tissues. It was found that $\mathrm{Zn}$ and $\mathrm{Mn}$ were also positively correlated with each other. It was found that there were no significant correlations between the concentrations of $\mathrm{Cu}$ in tissues and the concentrations of other metals in tissues. It has been suggested that relationships between weight-length and metal concentrations in the fish tissues are mostly positive (Pannetier et al. 2016). Cd concentrations in the liver tissue of eel were positively correlated with eel length (Pierron et al. 2008). Also, the length and weight of eels were positively correlated with the $\mathrm{Zn}$ concentration in muscle tissue of eel and negatively correlated with the concentrations of $\mathrm{Cd}, \mathrm{Cu}, \mathrm{Pb}$, $\mathrm{Hg}$, and As in muscle tissue of eel (Juszczak and Robak 2015). However, the fact that such variable relationships have been identified between the concentrations of HMs in eel tissues and their physical properties indicates that there is not always a strong relationship between the size of the fish and the concentrations of HMs deposited in their tissues. This variable relationship shows that except for the physical properties, metal accumulation is significantly dependent on the habitat, the eel's complex life cycle, pollutant sources, and biochemical processes. However, the studies showing that the reason for this variable relationship depends on the metabolic activity of the species should also be taken into consideration. Even in these studies, it is claimed that metabolic activity is generally higher in young fish than in old fish (Live and Horse 2003; Farkas et al. 2003).

344 Table 4 Spearman correlation coefficients between HM concentrations in tissues and height and weight of eel

\begin{tabular}{|c|c|c|c|c|c|c|c|c|c|c|c|c|c|c|c|c|c|c|c|c|c|c|}
\hline & $\mathrm{L}$ & W & $\begin{array}{c}\mathrm{Mn} \\
\mathrm{G}\end{array}$ & $\begin{array}{c}\mathrm{Cd} \\
\mathrm{G}\end{array}$ & $\begin{array}{c}\mathrm{Zn} \\
\mathrm{G} \\
\end{array}$ & $\begin{array}{c}\mathrm{Pb} \\
\mathrm{G}\end{array}$ & $\begin{array}{c}\mathrm{Cu} \\
\mathrm{G}\end{array}$ & $\begin{array}{c}\mathrm{Mn} \\
\mathrm{L}\end{array}$ & $\begin{array}{c}\mathrm{Cd} \\
\mathrm{L}\end{array}$ & $\begin{array}{c}\mathrm{Zn} \\
\mathrm{L}\end{array}$ & $\begin{array}{c}\mathrm{Pb} \\
\mathrm{L} \\
\end{array}$ & $\begin{array}{c}\mathrm{Cu} \\
\mathrm{L}\end{array}$ & $\begin{array}{c}\mathrm{Mn} \\
\mathrm{M}\end{array}$ & $\begin{array}{l}\mathrm{Cd} \\
\mathrm{M} \\
\end{array}$ & $\begin{array}{l}\mathrm{Zn} \\
\mathrm{M}\end{array}$ & $\begin{array}{l}\mathrm{Pb} \\
\mathrm{M}\end{array}$ & $\begin{array}{l}\mathrm{Cu} \\
\mathrm{M} \\
\end{array}$ & $\begin{array}{c}\mathrm{Mn} \\
\mathrm{S}\end{array}$ & $\begin{array}{c}\mathrm{Cd} \\
\mathrm{S}\end{array}$ & $\begin{array}{c}\mathrm{Zn} \\
\mathrm{S} \\
\end{array}$ & $\begin{array}{c}\mathrm{Pb} \\
\mathrm{S} \\
\end{array}$ & $\begin{array}{c}\mathrm{Cu} \\
\mathrm{S} \\
\end{array}$ \\
\hline $\mathrm{L}$ & $1^{*}$ & & & & & & & & & & & & & & & & & & & & & \\
\hline W & 0.79 & 1 & & & & & & & & & & & & & & & & & & & & \\
\hline $\mathrm{Mn} \mathrm{G}$ & 0.36 & 0.21 & 1 & & & & & & & & & & & & & & & & & & & \\
\hline $\mathrm{Cd} \mathrm{G}$ & 0.57 & 0.66 & 0.30 & 1 & & & & & & & & & & & & & & & & & & \\
\hline $\mathrm{Zn} \mathrm{G}$ & 0.62 & 0.59 & 0.61 & 0.58 & 1 & & & & & & & & & & & & & & & & & \\
\hline $\mathrm{Pb} \mathrm{G}$ & 0.16 & 0.30 & 0.02 & 0.00 & 0.17 & 1 & & & & & & & & & & & & & & & & \\
\hline $\mathrm{Cu} \mathrm{G}$ & 0.06 & 0.18 & 0.12 & 0.24 & 0.06 & 0.14 & 1 & & & & & & & & & & & & & & & \\
\hline Mn L & 0.37 & 0.17 & 0.58 & 0.35 & 0.61 & 0.24 & 0.08 & 1 & & & & & & & & & & & & & & \\
\hline $\mathrm{Cd} \mathrm{L}$ & 0.42 & 0.48 & 0.08 & 0.46 & 0.32 & 0.14 & 0.17 & 0.04 & 1 & & & & & & & & & & & & & \\
\hline $\mathrm{Zn} \mathrm{L}$ & 0.58 & 0.47 & 0.56 & 0.48 & 0.90 & 0.13 & 0.07 & 0.66 & 0.21 & 1 & & & & & & & & & & & & \\
\hline $\mathrm{Pb} \mathrm{L}$ & 0.41 & 0.51 & 0.10 & 0.40 & 0.29 & 0.44 & 0.34 & 0.14 & 0.50 & 0.17 & 1 & & & & & & & & & & & \\
\hline $\mathrm{Cu} \mathrm{L}$ & 0.33 & 0.25 & 0.33 & 0.09 & 0.61 & 0.12 & 0.04 & 0.49 & 0.18 & 0.61 & 0.03 & 1 & & & & & & & & & & \\
\hline Mn M & 0.65 & 0.56 & 0.48 & 0.65 & 0.70 & 0.04 & 0.03 & 0.54 & 0.31 & 0.67 & 0.24 & 0.30 & 1 & & & & & & & & & \\
\hline $\mathrm{Cd} \mathrm{M}$ & 0.22 & 0.36 & 0.22 & 0.22 & 0.38 & 0.33 & 0.19 & 0.13 & 0.23 & 0.35 & 0.32 & 0.33 & 0.39 & 1 & & & & & & & & \\
\hline $\mathrm{Zn} \mathrm{M}$ & 0.63 & 0.56 & 0.62 & 0.56 & 0.92 & 0.10 & 0.08 & 0.62 & 0.28 & 0.89 & 0.25 & 0.59 & 0.67 & 0.35 & 1 & & & & & & & \\
\hline $\mathrm{Pb} \mathrm{M}$ & 0.65 & 0.64 & 0.50 & 0.73 & 0.91 & 0.14 & 0.07 & 0.58 & 0.46 & 0.85 & 0.43 & 0.49 & 0.71 & 0.39 & 0.88 & 1 & & & & & & \\
\hline $\mathrm{Cu} \mathrm{M}$ & 0.13 & 0.27 & 0.20 & 0.29 & 0.01 & 0.29 & 0.29 & 0.24 & 0.30 & 0.05 & 0.53 & 0.21 & 0.02 & 0.18 & 0.02 & 0.15 & 1 & & & & & \\
\hline $\operatorname{Mn~S}$ & 0.05 & 0.15 & 0.02 & 0.08 & 0.02 & 0.43 & 0.17 & 0.31 & 0.22 & 0.06 & 0.28 & 0.03 & 0.09 & 0.26 & 0.05 & 0.00 & 0.26 & 1 & & & & \\
\hline $\mathrm{Cd} \mathrm{S}$ & 0.55 & 0.63 & 0.28 & 0.73 & 0.63 & 0.18 & 0.24 & 0.34 & 0.52 & 0.58 & 0.53 & 0.19 & 0.59 & 0.35 & 0.58 & 0.75 & 0.32 & 0.00 & 1 & & & \\
\hline $\mathrm{ZnS}$ & 0.58 & 0.50 & 0.59 & 0.55 & 0.90 & 0.14 & 0.05 & 0.57 & 0.26 & 0.86 & 0.27 & 0.56 & 0.72 & 0.37 & 0.87 & 0.85 & 0.00 & 0.03 & 0.59 & 1 & & \\
\hline
\end{tabular}


The degree of metal contamination

The $\mathrm{P}_{\mathrm{i}}$ was calculated by metal concentrations of eel for the assessment of metal pollution in LK and LV; the corresponding results have been shown in Table 5. To calculate the $\mathrm{P}_{\mathrm{i}}$, the tolerable limit values of the $\mathrm{Pb}$ and $\mathrm{Cd}$ as prescribed by some international regulatory bodies were used. According to the tolerable limit values proposed by TFC, Directive 2005/78/EC, UNEP, IAEA-407 and FAO/WHO, the $\mathrm{P}_{\mathrm{Cd}}$ in both lakes was determined as high contamination, high contamination, minor contamination, minor contamination, and no significant contamination, respectively. However, the $\mathrm{P}_{\mathrm{Pb}}$ was found to be at different levels in both lakes. According to the tolerable limit values proposed by all the international regulatory bodies, the $\mathrm{P}_{\mathrm{Pb}}$ in LV was found to be at high contamination. However, in $\mathrm{LK}$, the $\mathrm{P}_{\mathrm{Pb}}$ was found as high contamination according to FC, Directive 2005/78 / EC and IAEA-407, moderate contamination according to UNEP, and minor contamination according to $\mathrm{FAO} / \mathrm{WHO}$.

Table 5 The $\mathrm{P}_{\mathrm{i}}$ values of $\mathrm{Cd}$ and $\mathrm{Pb}$

\begin{tabular}{|c|c|c|c|c|c|c|}
\hline \multirow[b]{2}{*}{ Index } & \multirow[b]{2}{*}{ Location } & \multicolumn{5}{|c|}{ International Regulatory Bodies } \\
\hline & & UNEP & IAEA-407 & TFC & $\begin{array}{c}\text { Directive } \\
\text { 2005/78/EC }\end{array}$ & $\mathrm{FAO} / \mathrm{WHO}$ \\
\hline \multirow{2}{*}{$\mathbf{P}_{\mathbf{C d}}$} & L. Võrtsjärv & 0.22 & 0.36 & 1.32 & 1.32 & 0.13 \\
\hline & L. Köyceğiz & 0.21 & 0.34 & 1,24 & 1.24 & 0.12 \\
\hline \multirow{2}{*}{$\mathbf{P}_{\mathbf{P b}}$} & L. Võrtsjärv & 2.74 & 6.86 & 4.12 & 4.12 & 1.65 \\
\hline & L. Köyceğiz & 0.79 & 1.97 & 1.18 & 1.18 & 0.47 \\
\hline \multirow{2}{*}{ MPI } & L. Võrtsjärv & 0.211 & & & & \\
\hline & L. Köyceğiz & 0.203 & & & & \\
\hline
\end{tabular}

The MPI was used to compare the total metals accumulation level in the muscle of eels of both countries. MPI can be included in complex freshwater monitoring programs as it can produce some additional information about metal bioavailability, bio-concentration, and metal penetration into the environment. The MPI is a reliable and sensitive method for monitoring metal contamination in food samples (Zakir et al. 2019). In this study, the MPI value in LV was found to be slightly higher than the MPI value in LK. This result may indicate that there is slightly more metal contamination in LV than in LK.

Potential risks on human health

\section{Metal concentrations in muscle}

Since the most important accumulation mechanism of HMs is the food chain, there are many studies in the literature regarding the measurement of $\mathrm{HM}$ concentrations in the muscle tissues of fish (Table 6). Especially the detection of toxic metals whose limit values have been determined in the national and international codec is very important in terms of species that are connected by food chains. In this study, $\mathrm{Cd}$ and $\mathrm{Pb}$ concentrations in the muscle tissue of eel, which is consumed a lot in Europe, were determined and compared 


\begin{tabular}{lccl}
\hline Location & $\mathrm{Pb}$ & $\mathrm{Cd}$ & Ref \\
\hline River Turia & 0.1018 & 0.0049 & Bordajandi et al.2003 \\
River Gediz & $0.0032 \pm 0.003$ & $1.2067 \pm 1.278$ & Ylldı et al., 2010 \\
Atlantic coasts & 0.03 to 0.09 & 0.015 to 0.050 & Usero et al.,2003 \\
Camargue $^{1}$ & 0.21 to 0.79 & $n d$ & Oliveire Riberio et al., 2005 \\
Flanders & 0.038 to 0.053 & 0.002 to 0.019 & Maes et al., 2005 \\
Köyceğiz Dalyan Lagoon $^{1}$ & $1.07 \pm 0.11$ & $0.22 \pm 0.03$ & Genç and Y1lmaz, 2017 \\
North Luxembourg & 0.034 to 0.050 & 0.021 to 0.064 & Boscher et al., 2010 \\
Lake Albufera $^{\text {Mar Menor Lagoon }}$ & $0.02-0.30$ & $<0.02$ & Urena et al.,2007 \\
Lake Köyceğiz $^{1}$ & $0.299 \pm 0.051$ & $0.006 \pm 0.003$ & Romero et al., 2020 \\
Lake Võrtsjärv $^{1}$ & $0.24 \pm 0.05$ & $0.06 \pm 0.05$ & Our Study \\
UNEP & $0.82 \pm 0.50$ & $0.09 \pm 0.06$ & Our Study \\
IAEA-407 & 0.3 & 0.3 & UNEP \\
TFC & 0.18 & 0.12 & IAEA-407 \\
Directive 2005/78/EC & 0.1 & 0.3 & TFC \\
FAO/WHO & 0.1 & 0.3 & Directive 2005/78/EC \\
\hline
\end{tabular}

with the limit values and the results obtained from other studies (Table 6). All values measured in this study were found as dry weight. The limit recommended values of the FAO / WHO, national and intrenational codec were given in wet weight. Since the wet / dry weight ratio used for the conversions was determined for muscle as 3 (Urena et al. 2007), one-third of the values obtained in this study were compared with the limit recommended values. When the measured values were converted into wet weight, it was determined that only the the average concentrations of $\mathrm{Pb}$ in muscle of eels in LV slightly exceeded the limit recommended values of IAEA-407, TFC and Directive 2005/78 / EC. In many previous studies in different countries, very different values of Pb levels in many fish species were determined. Most of these values exceed the permissible limits set by the European Commissions and FAO (Sonkar et al. 2006; Sen et al. 2011; Mata et al. 2020; Akter et al. 2020).

According to Genç and Yllmaz (2017), the concentrations of $\mathrm{Pb}$ and $\mathrm{Cd}$ in musscle of eel samples in Köyceğiz Dalyan Lagoon were found approximately four times higher than the values obtained in this study (Table 6). Eel samples were collected in 2010-2011 in the study of Genç and Yllmaz (2017). So, the sampling was done 8 years before this study. For nearly ten years, the Turkish government has taken very serious preventions such as regulation of boat traffic, control of bilge water, improvement of waste water treatment facilities and continuous water quality monitoring programs against environmental pollution in the Köyceğiz region, which has been declared an environmental protection zone.

Table 6 Comparison of $\mathrm{Pb}$ and $\mathrm{Cd}$ concentrations in eel samples with literature and guidelines values $\left(\mu \mathrm{g} \mathrm{g}^{-1}\right)$

\footnotetext{
. dry weight. Ratio wet to dry weight used for transformations muscle=3 (Urena et al. 2007).
}

Health risk assessment

As fish is a vital source of nutrients, the accumulation of HMs in muscle tissue is of great importance from human health perspective. HM concentrations in the muscle tissue of eels from both lakes were measured 
Table 7 The EDI and ADI recorded for the different HMs detected in the eel (unit $\mu \mathrm{gkg}^{-1} \mathrm{bw}_{\mathrm{day}}{ }^{-1}$ for EDI)

\begin{tabular}{|c|c|c|c|c|c|}
\hline & \multicolumn{2}{|c|}{ Lake Köyceğiz } & \multicolumn{2}{|c|}{ Lake Võrtsjärv } & \multirow{2}{*}{$\mathrm{ADI}^{\mathrm{a}}$ (unit $\mu \mathrm{g} \mathrm{kg}^{-1}$ bw day ${ }^{-1}$ ) } \\
\hline & Adult & Children & Adult & Children & \\
\hline $\mathrm{Mn}$ & 0.013 & 0.012 & 10.05 & 8.798 & 140 (EPA 2018) \\
\hline $\mathrm{Cd}$ & 0.002 & 0.002 & 0.322 & 0.282 & 0.8 (JECFA' $\left.^{\mathrm{b}} 2011\right)$ \\
\hline $\mathrm{Zn}$ & 0.085 & 0.074 & 14.92 & 13.05 & 300 (JECFA 1982) \\
\hline $\mathrm{Pb}$ & 0.007 & 0.006 & 3.119 & 2.730 & $1.50\left(\mathrm{EFSA}^{\mathrm{c}} 2010\right)$ \\
\hline $\mathrm{Cu}$ & 0.050 & 0.044 & 3.687 & 3.226 & 500 (JECFA 1982) \\
\hline
\end{tabular}

${ }^{a}$ : Acceptable daily intake, ${ }^{\text {b}}$ : Joint FAO/WHO Expert Committee on Food Additives, ${ }^{\text {c }}$ : European Food Safety Authority

to evaluate the health risks of eel consumption for adults and children. The daily consumption of HMs was evaluated based on the HM concentrations in the muscle tissue of eels caught. Consumption rate limit values are given in Table 7. The mean EDIs of the HMs were higher in the eels from LV than those from LK. EDI values are calculated to measure both significant non-carcinogenic risk (THQ) and carcinogenic risk (CR) due to the intake of targeted HMs in the aquatic products (Liu et al. 2018; Keshavarzi et al. 2018; Ahmed et al. 2019). It was determined that the EDI values obtained for the eel in the selected lakes in both countries were very different. The values obtained from LV were higher than the values obtained from LK. Approximately, it was found that $\mathrm{Mn}$ values were 1000 times, $\mathrm{Pb}$ values were 500 times, $\mathrm{Zn}$ values were 200 times and $\mathrm{Cd}$ and $\mathrm{Cu}$ values were 100 times higher. The estimated daily intake value of $\mathrm{Pb}$ for eels in LV exceeds the acceptable limit value. The maximum daily intake was in the order of $\mathrm{Zn}>\mathrm{Mn}>\mathrm{Cu}>\mathrm{Pb}>\mathrm{Cd}$ in the eel from LK. However, the EDI follows the order of $\mathrm{Mn}>\mathrm{Zn}>\mathrm{Cu}>\mathrm{Pb}>\mathrm{Cd}$ in eel from $\mathrm{LV}$.

The target hazard quotient (THQ) of the eel samples in LK and LV for adult and children were calculated for each HM. The acceptable limit value for THQ recommended by EPA (2011) is 1 . THQ < 1 indicates that the exposure level is below the reference dose, and exposure to pollutants defines that there would be no adverse effects for lifetime consumption (Ahmed et al. 2019). The THQ values obtained for the European eels caught in both lakes was found to be below 1 for both adults and children for each HM. It is important to evaluate the Hazard Index (HI) which is taking into account multiple metals. If the HI value is greater than 1, it means that there is a health risk for consumers (Liu et al. 2018; Ahmed et al. 2019). The values of HI in this study have not exceeded the recommended limit, stating that consumers (adults and children) would not experience noncarcinogenic health effects for European eel consumption (Table 8). As a result, no risk is observed in developing chronic general effects due to the consumption of the eel in both lakes for each HM. Likewise, the muscle values in the HI index, which show the collective effects of all metals, are also below the acceptable limit. Even if this fish is consumed seven times a week, non-carcinogenic health effects risk values for human health caused by HM won't occur. However, the highest HI value was found in VK for adults and children (Table 8). The values obtained in this study are compatible with some studies for different fish species in different places (Miri et al. 2017; Hwang et al. 2017; Kwaansa-Ansah et al. 2019).

Table 8 HI values in Turkey and Estonia

\begin{tabular}{cccc}
\hline Country & $\begin{array}{c}\text { Exposure } \\
\text { frequency }\end{array}$ & \multicolumn{2}{c}{ HI } \\
& & Adult & Child \\
\hline Estonia & $7 \mathrm{TW}$ & $1.34 \mathrm{E}-03$ & $1.17 \mathrm{E}-03$
\end{tabular}




\begin{tabular}{cccc} 
& $3 \mathrm{TW}$ & $5.61 \mathrm{E}-04$ & $4.90 \mathrm{E}-04$ \\
& $1 \mathrm{TW}$ & $1.92 \mathrm{E}-04$ & $1.68 \mathrm{E}-04$ \\
& $1 \mathrm{TM}$ & $4.43 \mathrm{E}-05$ & $3.87 \mathrm{E}-05$ \\
\hline \multirow{4}{*}{ Turkey } & $7 \mathrm{TW}$ & $5.50 \mathrm{E}-06$ & $4.81 \mathrm{E}-06$ \\
& $3 \mathrm{TW}$ & $2.29 \mathrm{E}-06$ & $2.01 \mathrm{E}-06$ \\
& $1 \mathrm{TW}$ & $7.84 \mathrm{E}-07$ & $6.86 \mathrm{E}-07$ \\
& $1 \mathrm{TM}$ & $1.81 \mathrm{E}-07$ & $1.58 \mathrm{E}-07$ \\
\hline
\end{tabular}

422

\section{Carcinogenic risk (CR)}

$424 \mathrm{CR}$ of $\mathrm{Pb}$ and $\mathrm{Cd}$ were calculated and presented in Table 9. CR values above $10^{-6}$ are generally considered 425 unacceptable, CR values below $10^{-6}$ are considered insignificant, and CR values between $10^{-4}$ and $10^{-6}$ are 426 considered acceptable carcinogenic risks (EPA 2010). The values of $\mathrm{CR}$ for $\mathrm{Pb}$ were calculated lower than the 427 limit values in both lakes. In the study, all CR exposures in LK are negligible. However, the CR value of $\mathrm{Cd}$ in 428 VK is not below the negligible limit for both adults and children. If the eel is consumed every day of the week, it 429 is very close to the danger limits. However, it is a known fact that eel is not consumed every day of the week. 430 For this reason, the values obtained in the study are below the hazard limits.

431 Table $9 \mathrm{CR}$ values for $\mathrm{Cd}$ and $\mathrm{Pb}$

\begin{tabular}{|c|c|c|c|c|c|}
\hline \multirow{3}{*}{ Country } & \multirow{3}{*}{$\begin{array}{l}\text { Exposure } \\
\text { frequency }\end{array}$} & \multicolumn{4}{|c|}{ Metals } \\
\hline & & \multicolumn{2}{|c|}{$\mathrm{Cd}$} & \multicolumn{2}{|c|}{$\mathrm{Pb}$} \\
\hline & & Adult & Child & Adult & Child \\
\hline \multirow{4}{*}{ Estonia } & $7 \mathrm{TW}^{\mathrm{a}}$ & $2.02 \mathrm{E}-06$ & $1.77 \mathrm{E}-06$ & $2.65 \mathrm{E}-08$ & $2.32 \mathrm{E}-08$ \\
\hline & $3 \mathrm{TW}$ & $8.40 \mathrm{E}-07$ & $7.40 \mathrm{E}-07$ & $1.10 \mathrm{E}-08$ & $9.70 \mathrm{E}-09$ \\
\hline & $1 \mathrm{TW}$ & $2.90 \mathrm{E}-07$ & $2.50 \mathrm{E}-07$ & $3.80 \mathrm{E}-09$ & $3.30 \mathrm{E}-09$ \\
\hline & $1 \mathrm{TM}^{\mathrm{b}}$ & $6.70 \mathrm{E}-08$ & $5.80 \mathrm{E}-08$ & $8.70 \mathrm{E}-10$ & $7.60 \mathrm{E}-10$ \\
\hline \multirow{4}{*}{ Turkey } & $7 \mathrm{TW}$ & $1.10 \mathrm{E}-08$ & $9.76 \mathrm{E}-09$ & $5.75 \mathrm{E}-11$ & $5.03 \mathrm{E}-11$ \\
\hline & $3 \mathrm{TW}$ & $4.60 \mathrm{E}-09$ & 4.10E-09 & $2.40 \mathrm{E}-11$ & $2.10 \mathrm{E}-11$ \\
\hline & $1 \mathrm{TW}$ & $1.60 \mathrm{E}-09$ & $1.40 \mathrm{E}-09$ & $8.20 \mathrm{E}-12$ & $7.20 \mathrm{E}-12$ \\
\hline & $1 \mathrm{TM}$ & $8.20 \mathrm{E}-12$ & $3.20 \mathrm{E}-10$ & $1.90 \mathrm{E}-12$ & $1.70 \mathrm{E}-12$ \\
\hline
\end{tabular}

432 a: Times a week

433 a: Times a month

Conclusion

Accumulation of HM concentrations in the tissues of eels in two different countries and regions with two different climates and habitats were compared in this study. While the eels in LV are restocked and spend most of their life in freshwater, eels in LK can move between salty waters and freshwaters. This study was the first to compare the metal contamination of eels in two different conditions described above. The following results were obtained in the study.

$440 \square$ Metal pollution indexes in eels from LV were higher than metal pollution indexes obtained from LK. 

values in LV were found higher than in LK.

While the $\mathrm{Pb}$ concentration in eel tissues is high in lake $\mathrm{A}$, the concentration of $\mathrm{Cu}$ in lake $\mathrm{K}$ is high. It was determined that the concentrations of the metals except $\mathrm{Zn}$ were different from each other in the tissues of eel taken from the two lakes with completely different ecological structures.

Acknowledgment This research was funded by Muğla Sıtkı Koçman University Department of Scientific

Research Projects Coordination with project number BAP 17/147 and Estonian Environmental Investment Centre project T180209PKKH, Estonia-Russia Cross Border Cooperation Programme 2014-2020 project ER80

"Restocking of European eel as a measure of recovery of endangered species and preservation of natural diversity “, Estonian University of Life Sciences research and development fond project nr PM170155PKLJ and Estonian Research Council Grant PRG709.

Supplementary Information no supplementary material.

455

456

457

458

459

460

461

462

463

464

465

466

467

468

469

470

471

472

\section{Author contribution}

Ahmer Demirak: Cnnceptualization, writing original draft, reviewing and editing

Feyyaz Keskin: Eel samples collection (in Turkey and Estonia), digestion and analysis, literature researach and writing

Maidu Silm: Preparation, literature research editing

Deniz Y1ldız: Samples digestion and analysis, writing

Nedim Özdemir: Eel samples collection (in Turkey) and preparation, literature research

Priit Bernotas: Sample collection (in Estonia), preparation, editing.

Burak Ögül: Statistical analysis, sample collection , preparation, writing, editing.

Data availability All data obtained during this study are included in this published article.

\section{Declarations}

Ethics approval and consent to participate Not applicable (this paper does not contain studies involving human participants, or their tissues.)

Consent to publish Not applicable (this scientific paper does not contain any individual person's or institution's data in any form).

Competing interests The authors declare no competing interests.

\section{References}

Ahmed, A.S.S., Rahman, M., Sultana, S., S.M., Babu, O.F., Sarker, M.S.I. (2019). Bioaccumulation and heavy metal concentration in tissues of some commercial fishes from the Meghna River Estuary in Bangladesh and human health implications. Marine Pollution Bulletin, 145, 436-447.

Akter, M., Zakir, H.M., Sharmin, S., Quadir, Q.F., Mehrin, S. (2020). Heavy metal bioaccumulation pattern in edible tissues of different farmed fishes of mymensingh area, Bangladesh, and health risk assessment. Advances in Research, 21(4), 44-55. 
Aytekin, T., Kargın, D., Çoğun, H.Y., Temiz, Ö., Varkal, H.S., Kargın, F. (2019). Accumulation and health risk assessment of heavy metals in tissues of the shrimp and fish species from the Yumurtalik Coast of Iskenderun Gulf, Turkey. Heliyon, 5 (8), e02131.

Batista, B.L., Nacano, L.R., Freitas, R., Oliveira-Souza, V.C., Barbosa, F. (2012). Determination of essential $(\mathrm{Ca}, \mathrm{Fe}, \mathrm{I}, \mathrm{K}, \mathrm{Mo})$ and toxic elements $(\mathrm{Hg}, \mathrm{Pb})$ in Brazilian rice grains and estimation of reference daily intake. Food and Nutrition Sciences, 3(1), 129-134.

Batty, J., Pain, D., Caurant, F. (1996). Metal concerations in ells Anguilla anguilla from the Camargue region of France. Elsevier Biological Conservation, 76, 17-23.

Belpaire, C., Goemans, G. (2007). The European eel (Anguilla anguilla), a rapporteur of the chemical status for the water framework directive?. Life and Environment, 57 (4), 235-252.

Bernotas, P., Öğlü, B., Nõges, P. (2020). How do environmental factors affect the yield of European eel (Anguilla anguilla) in a restocked population? Fisheries Research, 230 (2020), 105649.

Bird, D.J., Rotchell, J.M., Hesp, S.A., Newton, L.C., Hall, N.G., Potter, I.C. (2008). To what extent are hepatic concentrations of heavy metals in Anguilla anguilla at a site in a contaminated estuary related to body size and age and reflected in the metallothionein concentrations?. Environmental Pollution, 151 (2008), 641-651.

Bordajandi, L.R., Gomez, G., Fernandez, M.A., Abad, E., River, J., Gonzalez, M.J. (2003). Study on PCBs, PCDD/Fs, organochlorine pesticides, heavy metals and arsenic content in freshwater species from the river Turia (Spain). Chemosphere, 53,163-71.

Byer, J.D., Lebeuf, M., Trottier, S., Raach, M., Alaee, et al. (2015). Trends of persistent organic pollutants in American eel (Anguilla rostrata) from eastern Lake Ontario, Canada, and their potential effects on recruitment. Science Total Environment, 529, 231-242.

Canli, M., Atli, G. (2003). The relationships between heavy metal (Cd, Cr, Cu, Fe, Pb, Zn) levels and the size of six Mediterranean fish species. Environmental Pollution, 121(1), 129-136.

Caron, A., Pannetier, P., Rosabal-Rodriguez, M., Budzinski, H., Lauzent, M., et al. (2016). Organic and inorganic contamination impacts on metabolic capacities in American and European yellow eels. Canada Journal Fish. Aquatic Science, http://dx.doi.org/10.1139/cjfas-2015-0473.

Carrasco., L., Barata. C., Garcia-Berthou, E. (2011). Patterns of mercury and methylmercury bioaccumulation in fish species downstream of a long-term mercury-contaminated site in the lower Ebro River (NE Spain). Chemosphere, 84(2011), 1642-1649.

Chiesa, L.M., Emanuela, Z., Maria, N., Sara, P., Enrica, F., et al. (2019). Food risk characterization from exposure to persistent organic pollutants and metals contaminating eels from an Italian lake. Food Additives\& Contaminants: Part A, 36 (5), 779-788.

Claveau, J., Monperrus, M., Jarry, M., Pinaly, H., Baudrimonth, M., et al. (2015). Spatial and seasonal variations of methylmercury in European glass eels (Anguilla anguilla) in the Adour estuary (France) and relation to their migratory behaviour. Environmental Science and Pollution Research, 22, 10721-10732.

Dehkordi, S., Fallah, A.A., Nematollahi, A. (2010). Arsenic and mercury in commercially valuable fish species from the Persian Gulf: Influence of season and habitat. Food and Chemical Toxicology, 48, 2945-2950.

Dekker, W. (2016). Management of the eel is slipping through our hands! Distribute control and orchestrate national protection. ICES Journal of Marine Science, 73(10), 2442-2452. 
Durrieu, G., Maury-Brachet, R., Girardin, M., Rochard, E., Boudou, A. (2005). Contamination by heavy metals $(\mathrm{Cd}, \mathrm{Zn}, \mathrm{Cu}$, and $\mathrm{Hg})$ of eight fish species in the Gironde estuary (France). Estuaries, 28, 581-591.

Eira, C., Torres, J., Miquel, J., Vaqueiro, J., Soares, A.M.V.M., Vingada, J. (2009). Trace element concentrations in Proteocephalus macrocephalus (Cestoda) and Anguillicola crassus (Nematoda) in comparison to their fish host, Anguilla anguilla in Ria de Aveiro, Portuga. Science of The Total Environment, 407, 991-998.

EPA (2000). Guidance for assessing chemical contaminant data for use in fish advisories, volume II. Risk assessment and fish consumption limits. EPA 823-B-00-008. Washington, DC: United States Environmental Protection Agency.

EPA (2008). Child-specific exposure factors handbook. EPA/600/R-06/096F. Washington, DC: National Center for Environmental Assessment Office of Research and Development.

EPA (2010). Risk-based concentration table. United States Environmental Protection Agency, Washington, DC.

EPA (2011). USEPA Regional Screening Level (RSL) Summary Table: November 2011 http://www.epa.gov/regshwmd/risk/human/Index.htm.

EPA (2019). Regional screening levels (RSLs) - equations. https://www. epa.gov/risk/regional-screening-levelsrsls-equations.

EUROFISH International Organisation. (2017).

European Commission. (2000). Directive 2000/60/EC of the European Parliament and of the Council establishing a framework for community action in the field of water policy. Of Journal Eueanr Union L. 327:1-72.

FAO (2008). The state of world fisheries and aquaculture. Food and Agriculture Organization of the United Nations, Rome.

FAO/WHO. (2006). Evaluation of certain contaminants in food: Sixty-fourth report of the joint FAO/WHO expert committee on food additives. WHO Technical Report Series. No. 930. WHO, Geneva.

Freese, M., Sühring, R., Pohlmann, J.D., Wolschke, H., Magath, V., et al. (2016). A question of origin: dioxinlike PCBs and their relevance in stock management of European eels. Ecotoxicology, 25, 41-55.

Geeraerts, C., Belpaire, C. (2010). The effects of contaminants in European eel: A review. Ecotoxicology, 19, 239-266.

Genç, T.O., Yılmaz, F. (2017). Metal accumulations in water, sediment, crab (callinectes sapidus) and two fish species (Mugil cephalus and Anguilla anguilla) from the Köyceğiz Lagoon System-Turkey: an index analysis approach. Bulletin of Environmental Contamination and Toxicology, 99,173-181.

Henry, F., Amara, R., Courcot, L., Lacouture, D., Bertho, M.L. (2004). Heavy metals in four fish species from the French coast of the Eastern English Channel and Southern Bight of the North Sea. Environment International. 30, 675-683.

Hwang, D.W., Kim, S.S., Kim, S.G., Kim, D.S., Kim, T.H. (2017). Concentrations of heavy metals in marine wild fishes captured from the southern sea of Korea and associated health risk assessments. Ocean Science Journal, 52, 527-536.

ICES (2019). Joint EIFAAC/ICES/GFCM Working Group on Eels (WGEEL).

Jia, Y., Wang, L., Qu, Z. (2017). Effects on heavy metal accumulation in freshwater fishes: species, tissues, and sizes. Environmental Science and Pollution Research, 24, 9379-9386. 
Juszczak, L.P., Robak, S. (2015). Macro and microelements in eel (Anguilla anguilla) from the northern regions of Poland. Journal of Elementology, 20 (2), 385-394.

Kangur, A., Kangur, P., Kangur, K., Ja“rvalt, A., Haldna, M. (2010). Anguillicoloides crassus infection of European eel, Anguilla anguilla (L.), in inland waters of Estonia: history of introduction, prevalence and intensity. Journal of Applied Ichthyology, 26 (2), 74-80.

Keshavarzi, B., Hassanaghaei, M., Moore, F., Mehr, M.R., Soltanian, S., et al. (2018). Heavy metal contamination and health risk assessment in three commercial fish species in the Persian Gulf. Marine Pollution Bulletin, 129, 245-252.

Kojadinovic, J., Potier, M., Corre, M.L., Cosson, R.P., Bustamante, P. (2007). Bioaccumulation of trace elements in pelagic fish from the Western Indian Ocean. Environmental Pollution, 146 (2), 548-566.

Kortei, N.K., Heymann, M.E., Essuman, E.K., Kpodo, F.M., Akonor, P.T., et al. (2020). Health risk assessment and levels of toxic metals in fishes (Oreochromis noliticus and Clarias anguillaris) from Ankobrah and Pra basins: Impact of illegal mining activities on food safety. Toxicology Reports, 7, 360-369.

Kosker, A.R. (2020). Metal and fatty acid levels of some commercially important marine species from the northeastern Mediterranean: benefits and health risk estimation. Environmental Monitoring and Assessment 192, 358.

Kwaansa-Ansah, E.E., Nti, O.S., Opoku, F. (2019). Heavy metals concentration and human health risk assessment in seven commercial fish species from Asafo Market, Ghana. Food Science Biotechnology, 28(2), 569-579.

Lanceleur, L., Schäfer, J., Chiffoleau, J.-F., Blanc, G., Auger, D., Renault, S., et al. (2011). Long-term records of cadmium and silver contamination in sediments and oysters from the Gironde fluvial-estuarine continuum - evidence of changing silver sources. Chemosphere, 85, 1299-1305.

Liu, Q., Liao, Y., Shou, L. (2018). Concentration and potential health risk of heavy metals in seafoods collected from Sanmen Bay and its adjacent areas, China. Marine Pollution Bulletin, 131, 356-364.

Maes, G.E., Raeymaekers, J.A.M., Pampoulie, C., Seynaeve, A., Goemans, G., Belpaire, C., et al. (2005). The catadromous European eel Anguilla anguilla (L.) as a model for freshwater evolutionary ecotoxicology: relationship between heavy metal bioaccumulation, condition and genetic variability. Aquatic Toxicology, $73,99-114$.

Mata, H.K., Sivalingam, P., Konde, J., Otamonga, J-P., Niane, B., Mulaji, C.K., et al. (2020). Concentration of toxic metals and potential risk assessment in edible fishes from Congo River in urbanized area of Kinshasa, DR Congo, Human and Ecological Risk Assessment: An International Journal, 26 (6), 16761692.

Mendiburu, F. (2020). Agricola:Statistical Procedures for Agricultural Research. R package version 1.3-3. https://CRAN.R-project.org/package=agricolae.

Miao, X., Hao, Y., Tang, X., Xie, Z., Liu, L., Luo, S., et al. (2020). Analysis and health risk assessment of toxic and essential elements of the wild fish caught by anglers in Liuzhou as a large industrial city of China. Chemosphere, 243 (2020), 125337.

Miri, M., Akbari, E., Amrane, A., Jafari, S.J., Eslami, H., Hoseinzadeh, E., et al. (2017). Health risk assessment of heavy metal intake due to fish consumption in the Sistan region, Iran. Environmental Monitoring and Assessment, 189, 1-10. 
Nõges, T., Anneville, O., Guillard, J., Haberman, J., Järvalt, A., Manca, M., et al. (2018). Fisheries impacts on lake ecosystem structure in the context of a changing climate and trophic state. Journal Limnology, 77 , $46-61$.

Öğlü, B., Bhele, U., Järvalt, A., Tuvikene, L., Timm, H., Seller, S., et al. (2020). Is fish biomass controlled by abiotic or biotic factors? Results of long-term monitoring in a large eutrophic lake. Journal of Great Lakes Research, 46 (4), 881-890.

Özdemir, N. (1998). Environmental Issues and DALKO (Cooperative Fisheries Dalyan), the Socio-Economic Structure of Köyceğiz Basin, Ph.D. Thesis, Department of Fisheries, Institute of Science, Ege University.

Pannetier, P., Caron, A., Campbell, P-G.C., Pierron, F., Baudrimont, M., Couture, P. (2016). A comparison of metal concentrations in the tissues of yellow American eel (Anguilla rostrata) and European eel (Anguilla anguilla). Science of the Total Environment, 569-570, 1435-1445.

Pierron, F., Baudrimont, M., Dufour, S., Elie, P., Bossy, A., Baloche, S., et al. (2008). How cadmium could compromise the completion of the European eel's reproductive migration. Environmental Science \& Technology, 42, 4607-4612.

R Core Team. (2020). R: A language and environment for statistical computing. R Foundation for Statistical Computing, Vienna, Austria. URL https://www.R-project.org/.

Rosabal, M., Pierron, F., Couture, P., Baudrimont, M., Hare, L., Campbell, P.G.C. (2015). Subcellular partitioning of non-essential trace metals ( $\mathrm{Ag}, \mathrm{As}, \mathrm{Cd}, \mathrm{Ni}, \mathrm{Pb}$, and $\mathrm{Tl}$ ) in livers of American (Anguilla rostrata) and European (Anguilla anguilla) yellow eels. Aquatic Toxicology, 160, 128-141.

Sankar, T.V., Zynudheen, A.A., Anandan, R., Nair, P.G.V. (2006). Distribution of organochlorine pesticides and heavy metal residues in fish and shellfish from Calicut region, Kerala, India. Chemosphere, 65, 583-590.

Sekhar, K.C., Chary, N.S., Kamala, C.T. (2004). Fractionation studies and bioaccumulation of sediment-bound heavy metals in Kolleru Lake by edible fish. Environment International, 29,1001-1008.

Sen, I., Shandil, A., and Shrivastava, V.S. (2011). Study for determination of heavy metals in fish species of the River Yamuna (Delhi) by Inductively Coupled Plasma Optical Emission Spectroscopy (ICP-OES). Advances in Applied Science Research, 2:161-166.

Sivaperumal, P., Sankar, T.V. and Viswanathan, N, P.G. (2007). Heavy metal concentrations in fish, shellfish and fish products from internal markets of India vis-a-vis international standards. Food Chemistry, 102, 612-620.

Topcuoglu, S., Kırbas, Oglu, C., and Gungor, N. (2002). Heavy metals in organisms and sediments from the Turkish Coast of the Black Sea, 1997-1998. Environment International, 27, 521-526.

Traina, A., Bono, G., Bonsignore, M., Falco, F., Giuga, M., Quinci, E.M., et al. (2019). Heavy metals concentrations in some commercially key species from Sicilian coasts (Mediterranean Sea): potential human health risk estimation. Ecotoxicology and Environment Safety, 168, 466-478.

Ubl, C., Dorow, M. (2015). A novel enclosure approach to assessing yellow eel (Anguilla anguilla) density in non-tidal coastal waters. Fisheries Research, 161, 57-63.

Usero, J., Izquierdo, C., Morillo, J., Gracia, I. (2003). Heavy metals in fish (Solea vulgaris, Anguilla anguilla and Liza aurata) from salt marshes on the southern Atlantic coast of Spain. Enviroment International, 29 (7), 949-956. 
Yang, L., Qiang, F.U., Gao, J., Gu, X.W., Bo, Y., Qiao, C.Y., Hua, Q.W. (2013). Concentrations and safety evaluation of heavy metals in aquatic products of Yancheng, Jiangsu province. Environment Science, 34 (10), 4081-4089.

Zakir, H.M., Eti, M.S.A., Quadir, Q.F., Mallick, S. (2019). Health risk assessment of heavy metal intake of common fishes available in the Brahmaputra River of Bangladesh. Archives of Current Research International, 19(2), 1-15.

Zerizghi, T., Yang, Y., Wang, W., Zhou, Y., J., Zhang, J., Yi, Y. (2020). Ecological risk assessment of heavy metal concentrations in sediment and fish of a shallow lake: A case study of Baiyangdian Lake, North China. Environmental Monitoring and Assessment, 192, 154.

Zhu, F., Qu, L., Fan, W., Wang, A., Hao, H., Li, X., et al. (2015). Study on heavy metal levels and its health risk assessment in some edible fishes from Nansi Lake, China. Environmental Monitoring and Assessment, 187,161 . 


\section{Figures}
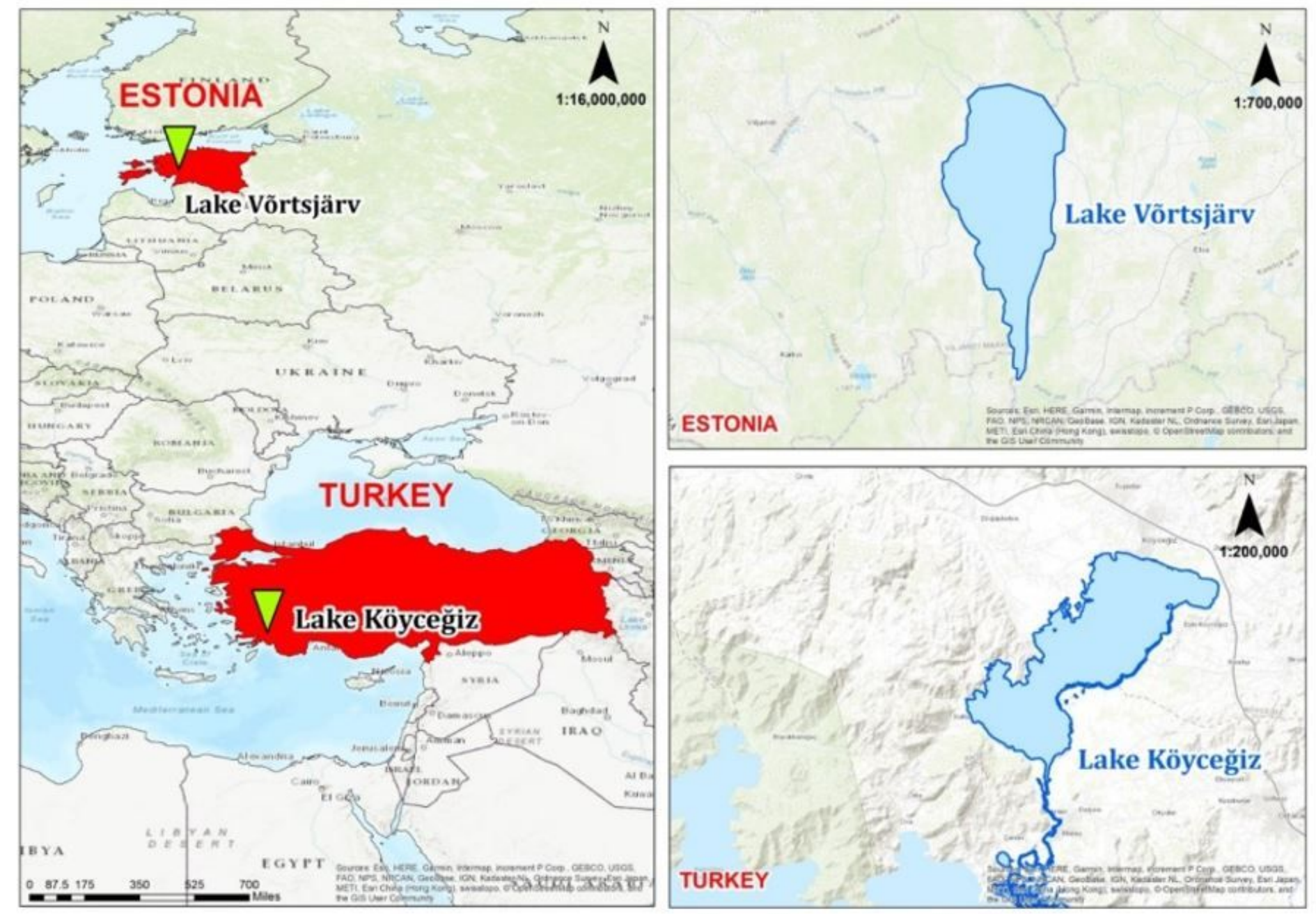

Figure 1

The map of the study area Note: The designations employed and the presentation of the material on this map do not imply the expression of any opinion whatsoever on the part of Research Square concerning the legal status of any country, territory, city or area or of its authorities, or concerning the delimitation of its frontiers or boundaries. This map has been provided by the authors. 

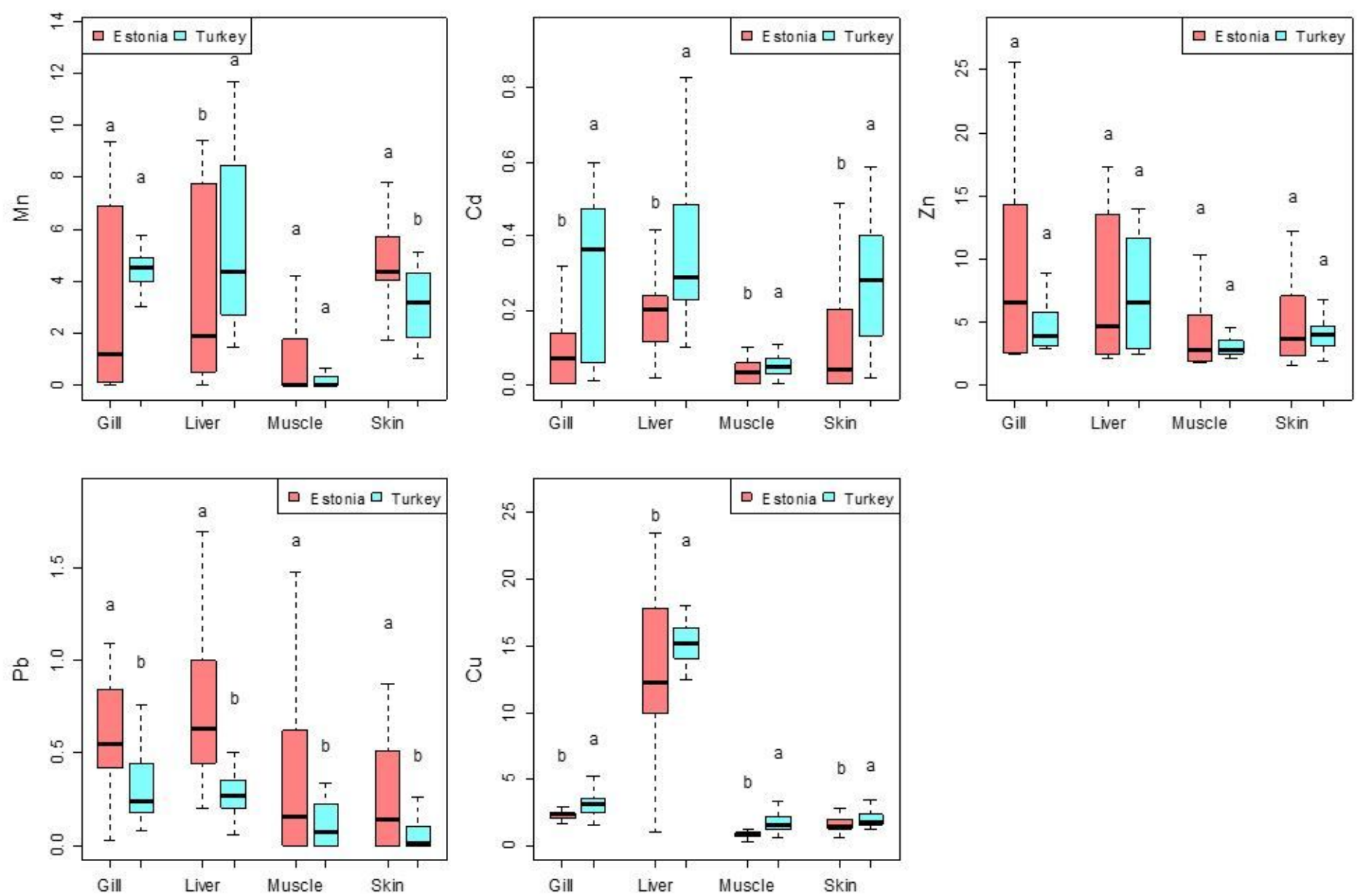

Figure 2

Boxplot comparison of HM concentrations in tissues of the eel 